\title{
Pengaruh Pemberian Tepung Ikan dengan Level yang Berbeda terhadap Pertumbuhan Itik Peking
}

Erna Menia

${ }^{a}$ Fakultas Pertanian, Universitas Timor, Kefamenanu, TTU - NTT, Indonesia.

\section{Article Info}

\section{Article history:}

Received 9 Desember 2017

Received in revised form 27 Desember 2017 Accepted 3 Januari 2018

DOI:

https://doi.org/10.32938/ja.v3i1.419

Keywords:

Pertumbuhan

Konsumsi

Konversi

Itik Peking

\section{Abstrak}

Penelitian ini di laksanakan selama 60 hari yang berlokasi di kilometer 7, Kelurahan Sasi, Kecamatan Kota Kefamenanu, Kabupaten, Timor Tengah Utara terhitung bulan Oktober- November 2017. Penelitian bertujuan untuk mengetahui pertumbuhan itik peking yang diberi tepung ikan dengan level berbeda. Penelitian menggunakan rancangan acak lengkap yang terdiri dari 4 perlakuan dan 4 ulangan. Perlakuan Ransum terdiri dari R0: Dedak padi 60\% +Jagung giling 20\% + 20 Tepung daun turi +Tanpa Tepung ikan R1: Dedak padi 60\% + Jagung giling 20\% + Tepung daun turi 20\% + Tepung ikan 2\% R2: Dedak padi 60\% + Jagung giling 20\% + Tepung daun turi 20\% + Tepung ikan $4 \%$ R3: Dedak padi $60 \%$ + Jagung giling $20 \%$ + Tepung daun turi $20 \%$ + Tepung ikan $6 \%$. Hasil analisis sidik ragam menunjukkan bahwa Pemberian Tepung Ikan dalam ransum memberikan pengaruh sangat nyata terhadap nilai pertambahan berat badan harian, konsumsi ransum itik peking. Disimpulkan bahwa pemberian tepung ikan pada level 6\% (R3) mampu menghasilkan pertambahan berat badan harian (PBBH) sebesar 20,56 g, sedangkan konsumsi ransum dan konversi ransum perlakuan $\mathrm{R}_{3}$ memiliki nilai yang lebih rendah dibanding perlakuan $\mathrm{R}_{0}, \mathrm{R}_{1}$, dan $\mathrm{R}_{2}$, sehingga dapat dikatakan bahwa ransum $\mathrm{R}_{3}$ telah memiliki nilai gizi yang cukup untuk memenuhi kebutuhan ternak serta dapat meningkatkan pertambahan berat badan ternak, menurunkan nilai konversi ransum dan menekan konsumsi pakan.

\section{Pendahuluan}

Permintaan daging saat ini mengalami kemajuan yang sangat pesat, yang dikarenakan semakin meningkatnya kebutuhan masyarakat akan daging sebagai salah satu sumber protein hewani. Salah satu ternak yang memberikan sumbangan protein terbesar adalah itik peking. Itik peking merupakan salah satu sumber daya penghasil daging yang memiliki nilai ekonomi yang tinggi Sekelompok itik bisa menghasilkan berbagai macam kebutuhan, terutama sebagai bahan makanan berupa daging, di samping hasil ikutan lainnya sebagai pupuk kandang dan bulu sebagai perhiasan. Secara umum itik memiliki ciri- cir pertumbuhan cepat yaitu sebagai penghasil daging, konversi pakan irit, siap dipotong pada usia relatif muda, serta menghasilkan kualitas daging. (Agustina, 2006) namun sering kali dijumpai bahwa ketersediaan ransum pabrik ditingkat peternak sering menjadi keluhan masyarakat peternak. Hal ini disebabkan karena ketersediaan ransum pabrik di pasaran tidak stabil dan harga relatif mahal.

Ransum merupakan bahan pakan yang bagian-bagiannya dapat dicerna dan diserap oleh itik. Untuk mendapatkan pertumbuhan itik yang lebih baik, maka perlu diperhatikan zat nutrisi pada ransumnya. Ransum yang digunakan terdiri dari jagung giling, tepung ikan, dedak padi tepung daun turi. Salah satu bentuk pemecahan masalah terhadap kelangkaan dan fluktuasi ransum pabrik adalah dengan menyusun ransum yang murah dan mudah didapat dengan memanfaatkan bahan lokal tersedia dimasyarakat. Ransum merupakan campuran berbagai macam bahan organik yang diberikan kepada ternak untuk memenuh kebutuhan zat-zat makanan yang diperlukan bagi pertumbuhan, perkembangan dan reproduksi agar pertumbuhan dan produksi maksimal, jumlah dan kandungan zat-zat makanan yang diperlukan ternak harus memadai (Suprijatna, 2008)

Konsumsi ransum yang tinggi diharapkan dengan berdampak terhadap produksi berat badan harian. Hal ini disebabkan karena nutrisi yang baik akan mampu dimanfaatkan oleh tubuh untuk pertumbuhan jaringan otot dan perkembangan tubuh. Diharapkan pemberian pakan adalah faktor yang sangat penting dalam meningkatkan pertumbuhan pada itik.

\section{Metode}

Penelitian ini telah dilaksanakan pada kandang percobaan dan berlokasi di km 7, Kelurahan Sasi, Kecamatan Kota Kefamenanu, Kabupaten TTU Penelitian berlangsung selama 2 bulan, dari tanggal 16 Oktober sampai dengan 29 November 2017. Peralatan yang digunakan adalah kandang terdiri dari enam belas petak dan tiap petak berukuran $1 \mathrm{x} 1 \mathrm{~m}$, tiap petak dilengkapi dengan tempa makan dan minum serta timbangan duduk kapasitas $2 \mathrm{~kg}$ untuk menimbang ternak dan pakan, timbangan digital, sekam sebagai alas kandang, paku, palu, gergaji, parang, pisau, alat tulis (buku dan pulpen), alat kebersihan seperti sapu dan ember serta kamera. Bahan-bahan yang digunakan dalam penelitian in adalah sebagai berikut: Bahan pembuat ransum buatan yang terdiri dari: dedak padi, jagung giling, tepung daun turi, dan tepung ikan. Ternak yang dipakai dalam penelitian adalah ternak itik yang berumur 3 minggu dalam proses pertumbuhan (Grower) sebanyak 32 ekor yang dibeli dari peternak itik peking d Kefamenanu. Ransum yang digunakan dalam penelitian ini adalah ransum buatan dengan komposisi seperti pada Tabel 1. dan komposisi kimia ransum ditunjukkan dalam Tabel 2.

Tabel 1. Komposisi Ransum untuk $100 \mathrm{~kg}$.

\begin{tabular}{clcccc}
\hline \multirow{2}{*}{ No. } & \multirow{2}{*}{ Bahan } & \multicolumn{4}{c}{ Komposisi Ransum (kg) } \\
\cline { 3 - 6 } & & R0 & R1 & R2 & R3 \\
\hline 1 & Dedak Padi & 60 & 60 & 60 & 60 \\
2 & Jagung Giling & 20 & 20 & 20 & 20 \\
3 & Tepung Daun Turi & 20 & 20 & 20 & 20 \\
4 & Tepung Ikan & - & 2 & 4 & 6 \\
\hline Jumlah & 100 & 100 & 100 & 100 \\
\hline
\end{tabular}

Penelitian ini menggunakan metode eksperimen dengan menggunakan Rancangan Acak Lengkap (RAL) yang terdiri dari 4 perlakuan dan 4 ulangan, sehingga terdapat 16 satuan percobaan. Adapun perlakuan yang akan diuji terdiri dari:

Ro: Dedak padi $60 \%$ + Jagung giling20\% + Tepung daun turi $20 \%$ + Tanpa Tepung ikan (Kontrol) R1: Dedak padi $60 \%+$ Jagung giling 20\% + Tepung daun turi $20 \%$ + Tepung ikan $2 \%$ R2 :Dedak padi $60 \%$ + Jagung giling $20 \%+$ Tepung daun turi $20 \%+$ Tepung ikan $4 \%$ R3 :Dedak padi $60 \%$ + Jagung giling $20 \%$ + Tepung daun turi $20 \%$ + Tepung ikan $6 \%$

Tabel 2. Komposisi Kimia Ransum

\begin{tabular}{ll}
\hline Kode Sampel & $\%$ PK \\
\hline R0 & 10,30 \\
R1 & 10,64 \\
R2 & 11,03 \\
R3 & 13,57 \\
\hline
\end{tabular}

Prosedur penelitian meliputi tahapan:

a. Tahap Persiapan kandang dan perlengkapan.

Kandang yang digunakan dalam penelitian ini adalah kandang individu yang terdiri dari kayu, tripleks yang beratap seng, kandang terdiri dari 16 petak dan dibagi dalam 2 blok di mana setiap blok terdiri dari 8 petak kandang dan tiap petak berukuran $1 \mathrm{x} 1 \mathrm{~m}$ yang dilengkapi tempat makan dan minum, sebelum kandang ditempati ternak, kandang tersebut terlebih dahulu disemprot dengan desinfektan agar kandang bebas dari kuman dan bakteri. Kandang diberi sekat pembatas dan dasar kandang dialasi dengan liter (sekam) untuk menjaga temperatur sekaligus menjaga kelembaban kandang.

b. Tahap pemberian pakan

Bahan dasar pembuatan pakan terdiri dari dedak padi, jagung giling, tepung daun turi, dan tepung ikan. Pembuatan pakan dilakukan dengan mengeringkan bahan dasar dengan metode pengeringan matahari selama 7 hari, selanjutnya bahan digiling dan dihaluskan dengan menggunakan mesin penggiling sampai bahan pakan berubah menjadi tepung setelah itu semua bahan pakan tersebut dicampur dan kemudian diberikan kepada ternak.

c. Tahap pemberian pakan dan air minum

Pemberian pakan dan air minum diberikan 2 kali sehari dengan penimbangan pakan dilakukan pada pagi hari. Pakan yang diberikan dalam bentuk tepung kemudian dicampur dengan air sebanyak 1 liter, karena itik peking tidak bisa mengonsumsi pakan dalam bentuk kering, jumlah pakan yang diberikan adalah $450 \mathrm{gr} / \mathrm{ekor} / \mathrm{hari}$.

Pertambahan berat badan yaitu selisih antara berat badan akhir dengan berat badan awal dibagi total hari penelitian (g/ekor/hari)

$$
\mathrm{PBB}=\frac{\text { Berat badan akhir }- \text { Berat Badan awal }}{t(\text { waktu })}
$$

Konsumsi ransum yaitu selisih antara jumlah pakan yang diberi dengan sisa pakan yang tidak dimakan dibagi total hari penelitian (g/ekor/ hari).

$$
\text { KonsumsiRansum }=\frac{p-s}{t}
$$

Keterangan:

p. Pakan yang diberi

s. Pakan sisa

t. Waktu Penelitian

Konversi Ransum (g) yaitu jumlah pakan yang dikonsumsi dibag pertambahan berat badan konversi ini dihitung seminggu sekali.

$$
\text { Konversi Ransum }=\frac{\text { Total Konsumsi Ransum }(g)}{\text { Pertambahan Berat Badan }(g)} X 100
$$


Data yang diperoleh dalam penelitian ini akan dianalisis dengan menggunakan analisis Sidik Ragam (ANOVA) berdasarkan rancangan acak lengkap.

\section{Hasil dan Pembahasan}

3.1 Pengaruh Perlakuan terhadap Pertambahan Berat Badan Harian

Pertambahan berat badan mencerminkan tingkat kemampuan itik dalam pencernaan ransum untuk diubah menjadi berat badan. Pertambahan berat badan ditentukan dengan cara mengurangkan berat badan akhir dengan berat badan awal (Amrullah, 2004). Pengaruh tingkat pemberian level tepung ikan terhadap nilai rataan pertambahan berat badan harian pada itik peking dapat dilihat pada Tabel 3.

Tabel 3. Rata-Rata Pertambahan Berat Badan Harian (g/ekor/hari)

\begin{tabular}{|c|c|c|c|c|c|c|}
\hline \multirow{2}{*}{ Perlakuan } & \multicolumn{4}{|c|}{ Ulangan } & \multirow{2}{*}{ Jumlah } & \multirow{2}{*}{ Rata-rata } \\
\hline & 1 & 2 & 3 & 4 & & \\
\hline R0 & 13,33 & 15,56 & 15,56 & 15,56 & 60,01 & $15,00^{\mathrm{c}}$ \\
\hline $\mathrm{R} 1$ & 14,44 & 15,56 & 17,78 & 16,89 & 64,67 & $16,17^{\mathrm{b}}$ \\
\hline $\mathrm{R} 2$ & 13,33 & 14,44 & 20,00 & 17,78 & 65,55 & $16,39^{\mathrm{b}}$ \\
\hline R3 & $17,78^{\mathrm{a}}$ & 20,00 & 23,33 & 21,11 & 82,22 & $20,56^{\mathrm{a}}$ \\
\hline Jumlah & 58,88 & 65,56 & 76,67 & 71,34 & 272,45 & \\
\hline Rata-rata & 14,72 & 16,39 & 19,17 & 17,84 & & 52,70 \\
\hline
\end{tabular}

Keterangan: Nilai dengan superskrip yang berbeda dalam kolom yang sama adalah berbeda nyata $(\mathrm{P}<0.01)$

Data pada Tabel 2. dapat dilihat bahwa rata-rata pertambahan berat badan harian itik peking yang tertinggi ditunjukkan pada perlakuan $\mathrm{R}_{3} 6 \%$ Tepung ikan yaitu sebesar $20,56 \%$ diikuti pemberian tepung ikan $4 \%$ sebesar $16,39 \%$ level $2 \%$ sebesar $16,17 \%$ dan terendah pada perlakuan R0 kontrol sebesar $15,00 \%$. Hal ini diduga kandungan protein pada tepung ikan dengan level $6 \%$ dalam ransum telah mencukupi asupan nutrisi dalam tubuh ternak sehingga mampu meningkatkan laju pertumbuhan ternak itik yang ditunjukkan dengan meningkatnya pertambahan berat badan harian itik tersebut.

Kholid (2011), menyatakan bahwa pemanfaatan tepung ikan dalam ransum untuk menjamin pemenuhan kebutuhan akan protein ternak yang sedang dalam masa pertumbuhan. Ransum yang diberikan pada itik peking harus memiliki gizi tinggi untuk mendukung pertumbuhan dan meningkatkan produktivitasnya. Pemberian ransum pada itik peking harus disesuaikan dengan kebutuhannya agar menghasilkan itik Peking dengan produksi tinggi (Ranto, 2007). Pada dasarnya pertumbuhan itik dipengaruhi oleh konsumsi nutrien yang meliputi protein, energi, mineral dan vitamin serta kemampuan kecernaan itik peking.

Berdasarkan hasil analisis sidik ragam, mengindikasikan bahwa penggunaan tepung ikan dalam ransum berpengaruh sangat nyata $(P<0,01)$ terhadap pertambahan berat badan harian itik peking. Hasil uji jarak berganda Duncan menunjukkan bahwa pada pasangan perlakuan $R_{3}-R_{2}, R_{3}-R_{1}, R_{3}-R_{0}$ dan $\mathrm{R}_{2}-\mathrm{R}_{0}$ memiliki perbedaan yang sangat nyata $(\mathrm{P}<0,01)$ terhadap nilai pertambahan berat badan harian itik peking. Sedangkan pada pasangan perlakuan $\mathrm{R}_{1}-\mathrm{R}_{0}$ dan $\mathrm{R}_{2}-\mathrm{R}_{1}$ menunjukkan tidak terdapat perbedaan ( $\left.\mathrm{P}>0,05\right)$, namun secara umum ternak yang diberi tambahan tepung ikan dalam ransum memiliki nilai pertambahan berat badan harian lebih tinggi dibanding ternak yang tidak mendapat tambahan tepung ikan dalam ransumnya bahwa pemakaian tepung ikan dalam metode penyusunan ransum pun dibatasi yaitu 5-10\%. (Kurniawan. Arry, 2014).

\subsection{Pengaruh Perlakuan terhadap Konsumsi Ransum}

Konsumsi merupakan jumlah makanan yang dimakan oleh seekor ternak, zat makanan yang dikandungnya dimanfaatkan untuk mencukupi kebutuhan hidup pokok dan produksi hewan tersebut (Yunilas, 2005). Konsumsi ransum yaitu selisih antara jumlah pakan yang diberikan dengan sisa pakan yang tidak dikonsumsi dibagi total hari penelitian (g/ekor/hari).

Tabel 4. Rataan Konsumsi Ransum (g/ekor/hari)

\begin{tabular}{|c|c|c|c|c|c|c|}
\hline \multirow{2}{*}{ Perlakuan } & \multicolumn{4}{|c|}{ Ulangan } & \multirow{2}{*}{ Jumlah } & \multirow{2}{*}{ Rata-rata } \\
\hline & 1 & 2 & 3 & 4 & & \\
\hline R0 & 218,27 & 219,42 & 217,31 & 219,23 & 874,23 & $218,56^{\mathrm{a}}$ \\
\hline R1 & 219,73 & 217,24 & 217,19 & 217,80 & 871,96 & $217,99^{\mathrm{a}}$ \\
\hline $\mathrm{R} 2$ & 215,60 & 216,33 & 216,44 & 216,49 & 864,86 & $216,22^{b}$ \\
\hline R3 & 212,24 & 211,18 & 213,18 & 214,56 & 851,16 & $212,79^{b}$ \\
\hline Jumlah & 865,84 & 864,17 & 864,12 & 868,08 & 3462,21 & \\
\hline Rata-rata & 216,46 & 216,04 & 216,03 & 217,02 & & 705,96 \\
\hline
\end{tabular}

Keterangan: Nilai dengan superskrip yang berbeda dalam kolom yang sama adalah berbeda nyata $(\mathrm{P}<0.01)$

Dari Tabel 4. terlihat bahwa nilai rataan tertinggi ditunjukkan pada perlakuan $R_{0}$ sebesar $218,56 \mathrm{~g}$ diikuti perlakuan $R_{1}$ sebesar $217,99 \mathrm{~g} ; \mathrm{R}_{2} 216,22$ $\mathrm{g}$ dan yang terendah $\mathrm{R}_{3} 212,79 \mathrm{~g}$. Hal ini menunjukkan bahwa pada perlakuan $\mathrm{R}_{3}$ konsumsi rendah karena energi pada ransum tinggi, sedangkan pada perlakuan R0 konsumsi tinggi karena energi pada ransum rendah. Suprijatna $d k k .$, (2005) menyatakan bahwa pakan starter diberikan pada itik berumur 0,3 minggu, sedangkan ransum finisher diberikan pada waktu itik berumur 4 minggu sampai panen. Konsumsi pakan merupakan jumlah pakan yang dimakan dalam waktu tertentu. Pakan yang dikonsumsi ternak untuk memenuhi kebutuhan protein.
Berdasarkan hasil analisis sidik ragam, mengindikasikan bahwa penggunaan tepung ikan dalam ransum memiliki perbedaan yang sangat nyata $(\mathrm{P}<0,01)$ terhadap konsumsi ransum. Hal ini disebabkan kandungan nutrisi yang terdapat dalam ransum seperti kandungan protein dan kandungan energi metabolisme yang berbeda sehingga mengakibatkan perbedaan pada konsumsi ransum tersebut

Hasil uji jarak berganda Duncan menunjukkan bahwa pada pasangan perlakuan $\mathrm{R}_{0}-\mathrm{R}_{3}, \mathrm{R}_{1}-\mathrm{R}_{3}, \mathrm{R}_{2}-\mathrm{R}_{3}$ dan $\mathrm{R}_{0}-\mathrm{R}_{2}$ memiliki perbedaan yang sangat nyata $(\mathrm{P}<0,01)$ terhadap nilai konsumsi ransum itik peking. Sedangkan pada pasangan perlakuan $\mathrm{R}_{0}-\mathrm{R}_{1}$, dan $\mathrm{R}_{1}-\mathrm{R}_{2}$ tidak terdapat perbedaan $(\mathrm{P}>0,05)$, hal ini diduga disebabkan oleh kandungan nutrisi dalam ransum pada perlakuan $R_{1}$ dan $R_{2}$ masih kurang sehingga ternak cenderung mengonsumsi ransum dalam jumlah banyak. Wahju, (2004) menyatakan bahwa besar dan bangsa itik, temperatur lingkungan, tahap produksi dan protein dalam pakan mempengaruhi konsumsi.

\subsection{Pengaruh Perlakuan terhadap Konversi Ransum}

Nilai konversi pakan dipengaruhi beberapa faktor antara lain genetik, tipe pakan yang digunakan, manajemen pemeliharaan dan suhu lingkungan (James, 2000). Jumlah pakan yang diberikan mempengaruhi perhitungan konversi ransum yakni perbandingan antara jumlah ransum yang dikonsumsi dengan pertumbuhan berat badan.

Tabel 5. Nilai Rataan Konversi Pakan (\%)

\begin{tabular}{|c|c|c|c|c|c|c|}
\hline \multirow{2}{*}{ Perlakuan } & \multicolumn{4}{|c|}{ Ulangan } & \multirow{2}{*}{ Jumlah } & \multirow{2}{*}{ Rata-rata } \\
\hline & 1 & 2 & 3 & 4 & & \\
\hline R0 & 16,37 & 14,10 & 13,97 & 14,09 & 58,53 & $14,63^{\mathrm{a}}$ \\
\hline $\mathrm{R} 1$ & 15,22 & 13,96 & 12,22 & 12,90 & 54,29 & $13,57^{\mathrm{b}}$ \\
\hline $\mathrm{R} 2$ & 16,17 & 14,98 & 10,82 & 12,18 & 54,15 & $13,54^{b}$ \\
\hline R3 & 11,94 & 10,56 & 9,14 & 10,16 & 41,80 & $10,45^{\mathrm{c}}$ \\
\hline Jumlah & 59,70 & 53,60 & 46,14 & 49,32 & 208,77 & \\
\hline Rata-rata & 14,93 & 13,40 & 11,54 & 12,33 & & 44,36 \\
\hline
\end{tabular}

Keterangan: Nilai dengan superskrip yang berbeda dalam kolom yang sama adalah berbeda nyata $(\mathrm{P}<0.01)$

Data pada Tabel 5. terlihat bahwa nilai rataan konversi pakan itik peking yang mengonsumsi ransum tanpa tambahan tepung ikan adalah 14,63 lebih tinggi dibanding itik peking yang mengonsumsi ransum dengan tambahan tepung ikan yaitu 13,57 pada perlakuan $R_{1}, 13,54$ pada perlakuan $R_{2}$ dan 10,45 pada perlakuanR $\mathrm{R}_{3}$. Bila dilihat pada konsumsi ransum dan pertambahan berat badan setiap perlakuan, akan terlihat jelas bahwa pada perlakuan $\mathrm{R}_{0}$ mengonsums pakan lebih tinggi dibanding perlakuan lainnya namun pertambahan berat badannya lebih kecil. Jumlah pakan yang diberikan mempengaruhi perhitungan konversi ransum merupakan perbandingan antara jumlah ransum yang dikonsumsi dengan pertumbuhan berat badan. Angka konversi ransum yang kecil berarti jumlah ransum yang digunakan untuk menghasilkan $1 \mathrm{~kg}$ daging semakin sedikit (Edjeng \& Kartasudjana, 2006). Semakin tinggi konversi ransum semakin boros ransum yang digunakan. (Fadilah $d k k$., 2007).

Hasil analisis sidik ragam, menunjukkan bahwa penggunaan tepung ikan dalam ransum berpengaruh sangat nyata $(\mathrm{P}<0,01)$ terhadap konversi pakan itik peking. Hasil uji jarak berganda Duncan menunjukkan bahwa pada pasangan perlakuan $R_{0}-R_{3}, R_{1}-R_{3}$ dan $R_{2}-R_{3}$ memiliki perbedaan yang sangat nyata $(\mathrm{P}<0,01)$ terhadap nilai konversi ransum itik peking. Sedangkan pada pasangan perlakuan $\mathrm{R}_{0}-\mathrm{R}_{1}, \mathrm{R}_{0}-\mathrm{R}_{2}$, dan $\mathrm{R}_{1}-\mathrm{R}_{2}$ tidak terdapat perbedaan ( $\left.\mathrm{P}>0,05\right)$, Hal ini diduga disebabkan semakin tinggi kandungan nilai gizi dalam ransum yang akan diberikan kepada seekor ternak maka ternak tersebut akan mengonversikan ransum tersebut dengan baik. Menurut Anggorodi, (1985) konversi ransum dipengaruhi beberapa faktor seperti umur ternak, bangsa, kandungan gizi ransum, keadaan temperatur dan keadaan ternak, tatalaksana dan penggunaan bibit yang baik.

\section{Kesimpulan}

Pemberian tepung ikan pada level 6\% dalam ransum (R3) mampu menghasilkan pertambahan berat badan harian (PBBH) sebesar 20,56 g, sedangkan konsumsi ransum sebesar212,79 gr dan konversi sebesar 10,45 gr ransum perlakuan $R_{3}$ memiliki nilai yang lebih rendah dibanding perlakuan $R_{0}$, $R_{1}$, dan $R_{2}$, sehingga dapat dikatakan bahwa ransum $R_{3}$ telah memiliki nilai gizi yang cukup untuk memenuhi kebutuhan ternak serta dapat meningkatkan pertambahan berat badan ternak, menurunkan nilai konversi ransum dan menekan konsumsi pakan.

Pustaka

Agustina 2006. Pengelolaan dan Pengendalian Limbah B3. Departemen Biologi - Fakultas Matematika dan Ilmu Pengetahuan Alam, Institut Bogor Bogor.

Amrullah 2004 Nutrien Ayam Broiler, Lembaga Satu Sulung Budi, Yogyakarta. Anggorodi, R. 1985.Ilmu Makanan Ternak Unggas. Penerbit Universitas Indonesia.

Edjeng dan Kartasudjana, R. 2006. Manajemen Ternak Unggas. Penebar Swadaya. Jakarta.

Fadilah R, A. Polana, S. Alam, dan E. Purwanto. 2007. Sukses Beternak Ayam Broiler Agromedia Pustaka, Jakarta.

James R. G. 2000. Pedoman Meramu Pakan Unggas. Gramedia Pustaka Utama. 
Kurniawan, A. 2004. Pengaruh Pemberian Jagung Pipil Terhadap Pertumbuhan Bobot Badan Ayam Kampung. IPB.

Ranto dan Sitanggang, Maloedyn.2007. Panduan Lengkap Beternak Itik. Jakarta: Agromedia Pustaka.

Suprijatna U. Atmomarsono, R. Kartasudjana. 2008. Ilmu Dasar Ternak Unggas. Penebar Swadaya, Jakarta.

Suprijatna E. Umiyanti, A. Ruhyat, 2005. Ilmu Dasar Ternak Unggas. Penebar Swadaya. Jakarta.

Yunilas 2005. Performa Ayam broiler yang Diberi Berbagai Tingkat Protein

Hewani Dalam Ransum. Jurnal Agribisnis Peternakan. Vol. 1, No. 1.

Wahju 2004. Ilmu Nutrisi Unggas. UGM. Yogyakarta. 